\title{
Representantes de governo, povos indígenas e outros atores na zona fronteiriça de Bolívia e Brasil - 1825-1879
}

Ernesto Cerveira de Sena ${ }^{1}$

\section{Resumo}

Este artigo trata da região fronteiriça entre a República da Bolívia e o Império do Brasil, após suas independências, até pouco depois da guerra do Paraguai. Além dos relacionamentos entre os governantes da área limítrofe, nos interessa perceber a diversidade das populações que habitavam ou transitavam pelo lugar, tendo elas também suas estratégias de ocupação, vivência e sobrevivência nessa área de fronteira. Se governantes iriam estabelecer ações e argumentos para ocupar determinados lugares, antes do tratado que definiria os limites, havia também várias pessoas, notadamente grupos indígenas, que procuravam sua maneira de vida, nessa área pretendida pelos novos Estados nacionais.

Palavras-chave: Fronteiras, Bolívia, Império do Brasil

\begin{abstract}
This article analyzes the border region between the Republic of Bolivia and the Empire of Brazil, just after their independence until the 1870's. In addition to the relationships between the rulers of neighboring area, we intend to understand the diversity of peoples who were living or moving through the place, which had also their occupation, living and surviving strategies at this border area. If governments would set up actions and arguments to occupy certain places before the treaty defining the limits between the two new countries, there were also several people, especially indigenous peoples, who were looking for their way of living in this area desired by the new National States.
\end{abstract}

Keywords: Borders, Bolivia, Brazil Empire

Artigo recebido em: 27/06/2013

Artigo aprovado para publicação em: 16/09/2013

\footnotetext{
${ }^{1}$ Doutor em História pela Universidade de Brasília. Professor de História da América na graduação e do Programa de Pós-Graduação em História da Universidade Federal de Mato Grosso (Brasil). Atualmente faz estágio pós-doutoral na Universidade Federal Fluminense. Desenvolve pesquisas sobre a fronteira entre a Bolívia e o Brasil, e sobre a História boliviana. Membro do grupo de pesquisa EPIFAN (Estudos de Política, Identidades e Fronteiras). E-mail: ernesto.sena@gmail.com
}

Revista Eletrônica da ANPHLAC, ISSN 1679-1061, n.15, p. 5-36, jul./dez. 2013. http://revista.anphlac.org.br/ 
Este artigo trata da região fronteiriça entre a República da Bolívia e o Império do Brasil, no período pós-independência e até pouco depois da guerra do Paraguai, quando se realizou a viagem de demarcação da fronteira, feita pelo militar Severiano da Fonseca. Interessam-nos não somente as relações entre governantes das unidades administrativas limítrofes, mas também a diversidade das populações que habitavam ou perpassavam por essa zona fronteiriça, pretendida e disputada pelos Estados nacionais que começavam a se formar. Se representantes estatais desenvolviam estratégias e ações antes do primeiro tratado de limites (1867), pessoas variadas também procuravam formas de vida ou de sobrevivência nessa área visada pelos governos nacionais.

Com a formação dos novos países na América do Sul, tornava-se imperativa a formação de limites entre eles, não sendo seus territórios um simples corolário do que tinham sido na época colonial. Pelo contrário, no caso de Bolívia e Brasil, por exemplo, nada estava garantido após as independências. Dessa maneira, eram necessárias muitas interpretações, diálogos, pressões, estratégias de ocupação, antes que o território fosse oficialmente delimitado, ao mesmo tempo em que os novos países procuravam se consolidar internamente. No entanto, se essa linha divisória entre dois ou mais países foi objeto de muitos estudos na área de relações internacionais, tal perspectiva pode, na maioria das vezes, mostrar as relações guiadas somente pelas capitais de seus países, deixando de lado a própria região fronteiriça. Nela, além dos representantes dos novos Estados nacionais que começavam a se formar, podemos ver como outros atores variados povos indígenas, escravos fugidos, criminosos perseguidos pela justiça, colonizadores, ribeirinhos, desertores, entre outros - agiam nessa região. Se a zona fronteiriça entre Bolívia e Brasil recebia influência das áreas e governantes centrais dos respectivos países, seus habitantes também apresentavam respostas próprias para o lugar em que viviam.

Partimos do pressuposto de que a formação de fronteiras lineares entre países, delimitando o que seria "um lado" e "outro lado", com traçado linear, foi característica, sobretudo, dos Estados nacionais no Ocidente, tornando-se para a maioria um fenômeno típico do século XIX (FOUCHER, 1986, p. 36). A formação de nações modernas teve sua especificidade na América, pois, segundo Pamplona e Doyle (2009, p. 18), elas não se "encaixavam no paradigma tradicional europeu", mesmo procurando imitá-los em

Revista Eletrônica da ANPHLAC, ISSN 1679-1061, n.15, p. 5-36, jul./dez. 2013. http://revista.anphlac.org.br/ 
muitos aspectos, notadamente nos institucionais, com propostas liberais. Normalmente, a "nação" era associada à etnicidade, entendida de maneira rígida. Para os autores, nas Américas, tanto a saxônica como a latina, possuíam populações diferentes das de origem, caracterizando-se por uma multietnicidade, com frações variadas de indígenas, africanos e seus descendentes, e uma crescente e diversificada presença de europeus que continuavam a migrar para o continente, além das inumeráveis miscigenações, o que tornava impossível, como na Europa, pensar em um "povo unido" e caracterizado pela ascendência comum, baseada em um "profundo passado coletivo ou tradições culturais hegemônicas" (PAMPLONA; DOYLE, 2009, p. 18-23). Daí a importância do território como fator de tentativa de coesão social, um ponto no qual os novos países poderiam ancorar a reivindicação de suas soberanias. Nesse sentido, é interessante percebermos uma mudança substantiva na ideia de território entre o tempo colonial, ou Antigo Regime, e o dos Estados nacionais, notadamente na América. Enquanto no primeiro a soberania residiria no rei, que possuía terras e possessões descontínuas, muitas vezes distribuídas por vários continentes, no segundo momento a soberania passaria para o "povo" - inclusive em suas "ficções democráticas" (GUERRA, 2009, p. 73-75) - que seria pensado em relação ao próprio solo no qual habitava, não mais situada no distante monarca. Assim, esse território simbolizaria o lugar que não só sustentaria com nutrientes físicos e simbólicos o "povo" que estava se forjando, mas legitimaria a nova soberania cindida da metrópole, mesmo que fosse ainda uma terra projetada, imaginada e não plenamente ocupada e reconhecida em seu interior e nas suas áreas de fronteira.

Foucher (2009) argumenta que, quando um país se quer soberano, seus limites são partes privilegiadas, integrando a "identidade nacional" em formação. O limite externo funcionaria "como um front potencial ou ativo", tendo não só papel militarestratégico, mas também como um fator de "segurança emocional alta e propícia para assegurar a preservação do futuro Estado" (FOUCHER, 2009, p. 26). No entanto, nessa construção nacional, era necessário, para os representantes do Estado, lidar com aqueles que moravam ou perpassavam pelas áreas fronteiriças e não se consideravam nem “bolivianos", nem "brasileiros". Não era o caso necessariamente das elites políticas no correr do oitocentos, que logo após as independências formaram verdadeiros mosaicos políticos, tanto na Bolívia - que se formou para fugir das pretensões de Buenos Aires e de Lima (ROCA, 2007, p. 335-359) - como no Brasil (JANCSÓ; PIMENTA, 1999, p.

Revista Eletrônica da ANPHLAC, ISSN 1679-1061, n.15, p. 5-36, jul./dez. 2013. http://revista.anphlac.org.br/ 
154-174), mas era o de muitos grupos que moravam ou percorriam a zona fronteiriça com interesses específicos que não a "construção da nação". Se para os europeus foi apontado o caráter voluntário de sua participação nas formações nacionais na América (PAMPLONA; DOYLE, 2009, p. 23), o mesmo não se pode dizer de variados grupos indígenas, nem da maioria de escravos e mesmo de seus descendentes, além daqueles que eram chamadas de "ribeirinhos",2 que viviam em várias partes da zona fronteiriça. Ou seja, para utilizar o termo bastante conhecido de Benedict Anderson (1989, p. 15 e ss.) sobre a nação ser uma "comunidade imaginada", ela não era imaginada por todos que estavam no mesmo território pretendido pelas novas autoridades como fundamento da nova nação ${ }^{3}$, inclusive por aqueles que estavam em lugares estratégicos como a zona fronteiriça, lugar onde, mais cedo ou mais tarde, deveria ser estabelecida uma linha, que se era imaginada, seria demarcatória nos mapas nacionais.

Entendemos a região ou zona de fronteira (ou complexo fronteiriço) entre o Império do Brasil e a República da Bolívia tal como proposta por Boccara (2005a, p. 38-45), não definida necessariamente pelo limite formal de Estado (como fora estabelecido nominal e institucionalmente pela primeira vez em 1867), mas pela imprecisão das áreas de influência governamental, a não presença constantemente fixa de grupamentos humanos, indo além de uma fronteira separada por uma linha, mas sendo, sim, a justaposição de várias fronteiras e seus arredores. Ou seja, havia grupos, como os genericamente chamados de índios ou ribeirinhos referidos anteriormente, que perpassavam ou viviam nesses lugares, sem necessariamente reconhecerem aquelas terras como pertencentes a um ou outro dos dois países limítrofes. Os povos indígenas, por formarem comunidades de tamanho variável, eram as pessoas por excelência que transitavam ou viviam nesses lugares fronteiriços, desafiando ou fazendo prevalecer

\footnotetext{
${ }^{2}$ Como o "índio" é uma generalização e construção histórica, também o é o "ribeirinho", habitante de lugares como os pantanais na região de fronteira entre Brasil, Bolívia e Paraguai, além dos amazônicos (BORGES, 2010).

${ }^{3}$ Apesar dos intentos homogeneizadores, elaborados e difundidos por políticos, homens de letras e professores ligados ao liberalismo revolucionário inicial, que previa escolas, difusão dos novos símbolos nacionais, construção de memórias históricas, entre outros intentos, as tentativas homogeneizadoras também produziam exclusões internas, estabelecendo hierarquias entre as populações que estavam mais próximas ou afastadas do padrão europeu. Isso iria se acentuar na segunda metade do século XIX. A ideia de produzir um "povo soberano" requeria uma "homogeneização" e, por sua vez, também formas de exclusões dentro do próprio território considerado nacional. Claro que havia vozes discordantes, mas essa direção somente começaria a mudar no final do século XIX (QUIJADA, 2000).
}

Revista Eletrônica da ANPHLAC, ISSN 1679-1061, n.15, p. 5-36, jul./dez. 2013. http://revista.anphlac.org.br/ 
suas soberanias territoriais, em situações diversas. Mesmo assim, não poderiam ser excluídos dos intentos governamentais para a construção do limite fronteiriço.

\section{Povos em fronteiras}

De uma enorme multiplicidade de povos americanos, havia uma classificação para contrastar com o europeu, desde o início da colonização, a de índio, como mostra Almeida (2010, p. 9-10). Dessa maneira, sendo os povos múltiplos, o contato entre europeus e indígenas também foi extremamente variado. As reações de ambos os lados, incluindo mestiços e negros, não poderiam ser outra que não fosse caracterizada pela diversidade, tanto no tempo como no espaço. Isso quebra ideias antigas de sociedades imutáveis, com tradições paralisantes e sistemas sociais rígidos, o que os levaria sempre a sucumbir diante da belicidade e ganância dos "brancos" e seus descendentes (BOCCARA, 2005b, p. 16). Pelo contrário, como mostra Almeida (2008, p. 21-22), em estudos sobre o período colonial e o século XIX, não são poucos os casos que demonstram que souberam escolher seu destino, fosse aliando-se a outros grupos indígenas para o confronto, fosse aproveitando a própria legislação vigente, interiorizando-se, ou mesmo "misturando-se" como condição de sobrevivência em vilarejos ou cidades, sem que, com isso, necessariamente perdessem sua identidade, inclusive criando novas identidades, como aponta Boccara (2005b, p. 30). Aproveitando ou camuflando sua condição indígena, diz Almeida (2011, p.105-106) sobre a formação nacional no oitocentos, podiam recorrer às várias leis que, se por vezes os colocavam como alvo, em outros momentos poderiam privilegiá-los, principalmente em países nos quais os sinais diacríticos não necessariamente demonstravam sua "casta" no século XIX (BAUD, 2006, p. 175).

Dessa maneira, desde o período colonial, espanhóis e portugueses disputavam a aliança ou a redução de povos que, por seu turno, também procuravam soluções para seus integrantes, fosse negociando, cedendo em alguma parte para compensar em outra, ou mesmo se aliando a outros grupos indígenas para fazerem frente às tentativas da colonização ibérica. Existiam regiões nas quais simplesmente europeus e mamelucos não conseguiram se instalar depois de muitas tentativas, como o atual sudoeste de Mato Grosso do Sul, sendo inclusive chamado de "terra mbaiânica", desde o século XVIII até a guerra do Paraguai, em 1865 (BASTOS, 1979, p. 131), onde os grupos provenientes

Revista Eletrônica da ANPHLAC, ISSN 1679-1061, n.15, p. 5-36, jul./dez. 2013. http://revista.anphlac.org.br/ 
do Chaco, se estabeleceram. Entre vários indígenas guerreiros, os mais conhecidos eram justamente os que tinham migrado da área chaquenha para as terras e águas pantaneiras, no vale do rio Paraguai e terras adjacentes; os nomeados por paiaguá e mbayá-guaicuru. Em determinado momento, os portugueses descobriram que os espanhóis de Assunção estavam estimulando os paiaguá, índios remadores, a atacar as monções carregadas de ouro. Logo, Assunção estava cheia de metais preciosos e escravos negros e mamelucos, crianças e mulheres descendentes de portugueses, prontos para serem negociados. Por outro lado, as autoridades portuguesas, depois de alguns fracassos, fizeram acordo, na segunda metade do XVIII, com parte dos denominados guaicuru, numa tentativa de melhorar a situação da capitania de Mato Grosso, pois as constantes guerras deixavam a situação da Fazenda Real na fronteira bastante combalida, além da insegurança que desestimulava

1. Dessa maneira, portanto, podemos dizer que os espanhóis e portugueses faziam parte da geopolítica dos indígenas que dominavam e percorriam um amplo território. Não eram somente os índios que eram úteis aos europeus e seus descendentes. O contrário também se dava, pois procuravam ganhos com os avanços e recuos dos ibéricos, inclusive em guerra contra outros indígenas ${ }^{2}$.

De acordo com a perspectiva do colonizador, os povos indígenas eram divididos entre "mansos" e "bravios" ou "bárbaros", guardando alguns matizes como "semicivilizados" ou civilizados, e isso não se alteraria muito no século XIX, tanto na Bolívia (JORDÁN, 2001, p. 272-284) como no Império do Brasil. Segundo Denise Maldi (1999), nas crônicas dos portugueses, dificilmente aparecia a palavra "tribo"; preferiam designá-los como "nações". Eram nações mansas e bárbaras, de acordo com a aceitação ou recusa à catequese e ao estabelecimento ou não de acordos. Esses fatores eram o que implicaria no reconhecimento político dos povos, sendo inclusive chamados de "confederados" na fronteira entre os impérios ibéricos. No entanto, o termo "nação", de acordo com a ressalva de um naturalista do final do XVIII, Alexandre Rodrigues Ferreira, não era a mesma coisa "como a alemã, a francesa, a portuguesa etc.", pois se referia a:

\footnotetext{
${ }^{1}$ Ver HOLANDA, 1986, p. 81-86; KOK, 2011, p. 5-8.

${ }^{2}$ Ver, por exemplo, FERREIRA, 2009.

Revista Eletrônica da ANPHLAC, ISSN 1679-1061, n.15, p. 5-36, jul./dez. 2013. http://revista.anphlac.org.br/
} 
[...] nações de índios, uma sociedade tão pequena e insignificante em número de indivíduos que às vezes não ultrapassam mais de 300, 400 e 600 almas. É para se admirar que algumas tão pequenas corporações ocupem às vezes espaços maiores que os maiores reinos da Europa. (FERREIRA, 1979 apud MALDI, 1997, p. 199)

Mesmo sendo "tão pequenos", na região de fronteira, esses povos tinham papéis nada desprezíveis, seja no período das coroas espanhola e portuguesa, seja depois, na zona de fronteira entre a República da Bolívia e o Império do Brasil.

Quando a República da Bolívia se formou, ela continha vários povoados na zona fronteiriça, que haviam sido erigidos principalmente no período colonial, os quais tinham tido variados propósitos, como a catequização e expansão da fé católica pelos jesuítas entre os índios, mas também para a contenção da expansão de mamelucos e portugueses que pretendiam atingir as áreas mineradoras dos Andes. Também serviam para os grupos indígenas se protegerem não somente dos que partiam de São Paulo, como também dos próprios espanhóis, que queriam submetê-los a trabalhos compulsórios, tomando-lhes as terras, além de outros ameríndios que os hostilizavam (COSTA, 2008, p. 167-176). Essas povoações, que passaram a ser chamadas de Chiquitos, reuniam dezenas de etnias e foram fundadas depois de várias incursões de espanhóis, procurando ao norte, nordeste e noroeste de Assunção, principalmente, o país do "Dorado", ou o "país fabuloso", "el Paititi” (RECIO, 1988, p. 28). Instigavam-nos os poucos exemplares de metais preciosos que encontravam com alguns indígenas. Assim, para manter uma base de apoio para o avanço de outras áreas, fundavam povoados. No entanto, muitas dessas incursões eram fortemente rechaçadas, e os povoados, destruídos pelos grupos ameríndios que defendiam sua região. A defesa do território por parte de vários povos indígenas fez, por exemplo, que Santa Cruz de la Sierra mudasse de lugar três vezes, estabelecendo-se finalmente à beira do rio Piraí, no início do século XVII, sendo por um bom tempo um dos poucos núcleos habitacionais espanhóis nas terras baixas da audiência de Charcas (RECIO, 1988, p. 16).

Se as missões de Chiquitos acabaram servindo como uma proteção contra a entrada de portugueses e mamelucos, dos que desejavam chegar às famosas minas de Potosí, além de local resistente aos empreendimentos espanhóis, não foram muito diferentes as missões de Mojos, que também começaram a se instalar no final do século XVII, com vários grupos indígenas diferentes formando os maiores complexos Revista Eletrônica da ANPHLAC, ISSN 1679-1061, n.15, p. 5-36, jul./dez. 2013. http://revista.anphlac.org.br/ 
missionais, junto com os da chiquitania, depois das missões guaranis. Apenas em 1723, os portugueses ficaram sabendo de sua existência, nas imediações do rio Beni, quando uma expedição subiu o rio Mamoré. A partir de então, passaram a centrar sua ação na ocupação do oeste, com uma política aguerrida, estabelecendo ações contra as missões, com o propósito de retirar os "índios espanhóis" (MALDI, 1997, p. 197). A criação da capitania de Cuiabá e Mato Grosso (1748) teve justamente o objetivo de se projetar nas terras que eram banhadas pelos rios que corriam para a Amazônia e o Paraguai. Dessa maneira, imaginavam forças rivais imensas e aplicaram esforços enormes para a construção de fortes, como o gigantesco Real Forte Príncipe da Beira (MALDI, 1997, p. 197-198), construído em apenas seis anos no Guaporé. Foi formada, portanto, uma nova zona de contato, que procurava instituir uma nova fronteira, baseada nas ações do Estado português, mas que por lá, no século XIX, por exemplo, quase nenhum viajante passava (FONSECA, 1986, p. 63).

O acordo com um povo indígena, no tempo colonial, não seria necessariamente para reduzi-lo em missões. Ele poderia viver em seu território. Na visão dos portugueses, o grupo indígena que tivesse participado do batizado e feito trato de aliança, teria estabelecido sua vassalagem ao rei de Portugal, "caracterizada por unir todos esses povos" fiéis ao monarca (MALDI, 1997, p. 202), podendo, portanto, viver em seu próprio solo. Um grande papel, tanto desses índios como dos que iam para a fronteira, era atrair os "índios espanhóis" para a esfera de influência portuguesa ou de seus índios "confederados". Principalmente a partir da política pombalina, de criação de diretórios, na década de 1750, povoados inteiros foram fundados, compostos quase apenas por ameríndios, como foi Vila Maria (hoje Cáceres), na beira do rio Paraguai, formada praticamente pelos que haviam abandonado os "domínios de Castela" (VOLPATO, 1987, p. 71). Ao mesmo tempo, era estimulado o casamento entre não indígenas e os que povoavam a região, numa tentativa de fixação de pessoas para assegurar determinado território ${ }^{3}$. Dessa maneira, se com as missões de Chiquitos e Mojos os espanhóis procuravam barrar a entrada de portugueses e mamelucos, os lusos, por sua vez, com as alianças e a fundação de povoados e fortes, pensavam em não

\footnotetext{
${ }^{3} \mathrm{Na}$ fronteira sul, por exemplo, Garcia (2007) mostra as disputas por povos indígenas pelas Coroas ibéricas e como esses grupos também estabeleceram estratégias e condições frente aos interesses das monarquias europeias.
}

Revista Eletrônica da ANPHLAC, ISSN 1679-1061, n.15, p. 5-36, jul./dez. 2013. http://revista.anphlac.org.br/ 
retroceder frente ao avanço já estabelecido a oeste, desde o início da ocupação/colonização, na área que veio a ser Mato Grosso. As relações com os indígenas, a partir do período pombalino, contribuíram para isso.

Provavelmente a expulsão dos jesuítas dos reinos espanhóis, em 1767, tenha tido muito mais efeito na região fronteiriça do que sua expulsão anterior do império português, em 1759. As administrações realizadas por curas ou laicos que substituíram a ordem inaciana passaram a cobrar mais trabalho dos indígenas, a ofertar menos produtos, além de praticamente suprimir seu tempo para as próprias roças e, inclusive, para o sagrado. A tudo isso, foram somados os maus-tratos, o que provocou, além de rebeliões nas ex-missões de Chiquitos e Mojos, a migração para outras áreas, consideradas pelos portugueses como seus domínios (Os lusos não incentivavam somente a migração dos povos indígenas aldeados, mas também a rebelião nas localidades espanholas (CARVALHO, 2012, p. 5-14; BASTOS, 1974). Como explica Vangelista (2011, p. 45) sobre a percepção dos índios aldeados ou missionados, "à obediência a regras dos invasores de seus territórios deviam ser compensados pela abundância de bens não produzidos pelos índios”. O desapego de alguns aspectos da vida do grupo, como morar em reduções ou prestar serviços, deveria ser satisfatoriamente recompensado, pois a troca era fundamental em boa parte, pelo menos nas relações interétnicas. Quando isso acaba, portanto, não há mais como manter a redução. Foram necessários novos reordenamentos, para que não fossem fatalmente despovoadas as ex-missões de Mojos e Chiquitos (BASTOS, 1974, p. 45-63), que procuravam continuar a fazer o papel de contramuro em relação aos domínios portugueses e, depois, às pretensões territoriais do Império do Brasil.

\section{Novos países, primeiros relacionamentos.}

Com as guerras de independência, aconteceu uma nova onda de migração dos chiquitano para o que veio ser consolidado como território do Brasil. Quando as tropas independentistas estavam perto de tomar Santa Cruz de la Sierra, dando a entender que logo chegariam à província de Chiquitos, muitos resolveram se mudar. Há vários apontamentos que relacionam a recalcitrância ou negação dos povos indígenas em aceitar os movimentos independentistas, por verem no rei uma forma de justiça e proteção de sua terra e de seu povo, enquanto outros aderiram, por não terem visto seus

Revista Eletrônica da ANPHLAC, ISSN 1679-1061, n.15, p. 5-36, jul./dez. 2013. http://revista.anphlac.org.br/ 
anseios atendidos pelas novas administrações do período bourbônico (ALMEIDA, 2011, p. 111-114). Nesse momento, em 1825, entre 9 de novembro e 29 de dezembro, foi contada a entrada em terras brasileiras de 126 espanhóis, não índios (VOLPATO, 1987, p. 70-71), entre eles, muito provavelmente, estava d. Sebastián Ramos, então governador de Chiquitos, que seguiu acompanhado de muitos chiquitano, bens das igrejas das ex-missões, além de gado. Seckinger (1985) relata que passaram para o Império ao todo 603 chiquitano, mas que já em dezembro voltaram para seus antigos lugares "unos 130" (p. 12-17). A volta desses índios teria inclusive acalmado os ânimos em relação a um iminente conflito com o Império.

A principal polêmica se dava, porque Vila Bela, lugar fundado para ser capital de Mato Grosso, tinha enviado tropa para anexar a província chiquitana, a pedido de d. Sebastián Ramos, sem, no entanto, ter sido autorizado pelo governo central do Império. A tropa regressou do povoado de San Miguel debaixo de uma insurreição e sob ameaça das tropas libertadoras, notadamente a comandada por Sucre. Ao mesmo tempo, quando d. Pedro, na Corte, soube da invasão, mandou imediatamente a tropa se retirar. Como as correspondências demoravam meses, por pouco não houve um conflito entre os independentistas e o Império do Brasil. Não faltaram generais libertadores dispostos a prolongar a guerra indo para o leste, o que foi recusado por Bolívar (ver CALÓGERAS, 1998, p. 419-423; SECKINGER, 1985 p. 9-17; SANTOS, 2002, p. 24-31).

Mas a demora entre os ocorridos em Chiquitos e a resposta imperial levou o historiador boliviano Ovando Sanz (1986) a concluir que o governo imperial havia aguardado algum tempo para ver se iria ser concretizada de fato a invasão brasileira. Foi somente quando percebeu que não teria resultado, que resolveu rechaçar a atitude tomada pelos moradores de Mato Grosso (SANZ, 1986, p. 121). O historiador e diplomata brasileiro Villafañe Gomes Santos (2002) defende que as atitudes precipitadas, tomadas na província limítrofe do Brasil, não correspondiam à política exterior brasileira. A margem oriental do rio da Prata, incorporada por d. João VI, ainda em 1816, representava tensões maiores para o Império que se formava. Reclamações por parte das Províncias Unidas do Prata já vinham se intensificando desde 1823, devido à presença brasileira na Banda Oriental, apontando para o iminente conflito aberto. Essa região era extremamente estratégica para o Império, pois não somente assegurava interesses dos pecuaristas do sul, como de financistas brasileiros na região,

Revista Eletrônica da ANPHLAC, ISSN 1679-1061, n.15, p. 5-36, jul./dez. 2013. http://revista.anphlac.org.br/ 
assim como poderia garantir navegação pelos rios da bacia do Prata. O conflito na Banda Oriental estourou em 1826. Para Gomes Santos (2002), abrir um outro flanco bélico na região de Chiquitos e se colocar em guerra contra as tropas de Bolívar em nada interessava ao Império. As diretrizes da Santa Aliança, que condenavam governos republicanos, não eram motivadoras o suficiente para uma aventura na fronteira oeste do Brasil (SANTOS, 2002, p. 26).

No entanto, Buenos Aires enviou missões especiais ao Chile e ao Peru e, depois, em 1825, à Bolívia e à Grã-Colômbia, a fim de conseguirem apoio para retirar o Brasil da Banda Oriental, e "vingar o insulto que as tropas brasileiras fizeram às armas do Libertador" (SANTOS, 2002, p. 28). Eles atacariam na parte "mais débil do Império", ao mesmo tempo em que outras forças deflagrariam o conflito na Cisplatina, sugeriam os representantes portenhos. Mas Bolívar, inclusive durante a invasão de Chiquitos, foi bastante cauteloso em se embrenhar em algum conflito com o Império. Na verdade, precisaria dele para reconhecimento internacional. Não interessava nem ao principal comandante das tropas independentistas, nem ao governo imperial, uma disputa bélica, sendo que as áreas de interesses divergentes não se apresentavam como as mais importantes. Além disso, a Inglaterra se mostrava como a principal aliada de ambos os lados, não interessando a ela o prolongamento de mais guerras, tendo em vista o potencial de investimentos e comércio que a América poderia representar após se desvencilhar de suas metrópoles. Foi assim que representantes da Inglaterra, maior força mercantil e de guerra do mundo, reforçaram a ideia entre líderes hispano-americanos, como Bolívar e Santander, da não intervenção na questão da Cisplatina, ao mesmo tempo em que conseguiam arbitrar um acordo entre Buenos Aires e Rio de Janeiro, em 1828, criando o Uruguai, nominalmente um novo país independente ${ }^{4}$. A Argentina se via frustrada na tentativa de formar uma coligação para atacar o Império (MELLO, 1963, p. 121-217).

\section{Povos na fronteira}

Logo depois dessa onda de migração que partiu de Chiquitos, em temor ao conflito, os dirigentes da província de Mato Grosso não deixaram de tentar atrair os

\footnotetext{
${ }^{4}$ Para Cervo e Bueno (2011, p. 29), o expansionismo no sul foi antes uma "herança portuguesa" do que "uma meta política nacional".

Revista Eletrônica da ANPHLAC, ISSN 1679-1061, n.15, p. 5-36, jul./dez. 2013. http://revista.anphlac.org.br/
} 
indígenas chiquitano para a parte que seria brasileira. Em 1826, em um ofício, o comandante Ribeiro da Fonseca solicitava que o capitão ajudante Vicente Leite Pereira tomasse providências urgentes e rápidas em relação aos índios que estavam na fronteira, que se mostravam ainda indecisos se permaneceriam na província. Para isso, disse para o capitão ordenar ao tenente Manoel Antunes de Frias, "versado na linguagem dos índios aí existentes", que mostrasse tudo o que podiam oferecer, "a fim de convencê-los por meio de maneiras dóceis do projeto adotado da melhoria do terreno", que tinha sido ofertado a eles para viverem. Também lhes prestariam "suave transporte" até o lugar. O militar ainda ordenava que, de fato, se prestassem todos "os socorros" nas suas necessidades de locomoção, e que era necessário fazer uma lista com o nome dos casais e das famílias, separando já quais eram "tidos como colonos".

Claro que índios já aldeados seriam muito mais úteis para áreas consideradas escassamente povoadas, pois já eram tidos como pessoas que possuíam ofícios "civilizados" ou poderiam trabalhar na agricultura. Por outro lado, as autoridades bolivianas também atraíam os "novos brasileiros", inclusive abrigavam fugitivos acusados de várias mortes, como foi o caso de 17 presos que evadiram-se da cadeia de Vila Bela após degolar o carcereiro ${ }^{6}$. O governo boliviano se recusou em devolvê-los, entregando somente as armas, além de afastá-los da zona fronteiriça ${ }^{7}$. Em dado momento, o presidente de província acusava o governador de Santa Cruz não só de ceder a bolivianos terras na região fronteiriça, as quais ainda não tinham sido demarcadas, como também de "chamar brasileiros" para ocuparem terrenos sem terem tal direito ${ }^{8}$.

$\mathrm{Na}$ verdade, ambos os países estavam abertos à migração, não somente para grupos indígenas. Já em 1826, os bolivianos fizeram ofertas de cessão de terras a quem migrasse para o seu país, repetindo outras vezes o dispositivo (JORDÁN, 2001, p. 270). Mas o oriente boliviano, que fazia fronteira com o Brasil, continuou sendo considerado muito pouco povoado. Como faz notar Pilar García Jordán (2001, p. 268), existia um

\footnotetext{
${ }^{5}$ Arquivo Público de Mato Grosso (APMT). Caixa 1826. Ofício avulso. Comandante Constantino Ribeiro da Fonseca para capitão ajudante Vicente Rebelo Leite Pereira. 18 de setembro de 1826.

${ }^{6}$ APMT. Registro de Correspondência com as Províncias e a Bolívia. (RCPB). José Antônio Pimenta Bueno para D. Marcelino de La Peña. Cuiabá, 8 de março de 1837.

${ }^{7}$ APMT. RCPB. José Antonio Pimenta Bueno para D. Marcelino de la Peña. Cuiabá, 10 de junho de 1837.

${ }^{8}$ APMT. RCPB. José Antonio Pimenta Bueno para Duarte da Ponte Ribeiro, Encarregado de Negócios do Brasil em Chuquisaca. Cuiabá, 10 de junho de 1837.
}

Revista Eletrônica da ANPHLAC, ISSN 1679-1061, n.15, p. 5-36, jul./dez. 2013. http://revista.anphlac.org.br/ 
discurso frequente sobre espaços "vazios", representando a "invisibilidade" dos povos que moravam nessas regiões, notadamente os que não tinham se sedentarizado e estabelecido contatos frequentes e amigáveis com as localidades de não índios. Portanto, eram considerados espaços vazios os que possuíssem índios tidos como "nômades" (pois suas concepções de território eram bastante diferentes) e, como consequência, também "bárbaros”. De acordo com García Jordán (2009), foi no período do governo Ballivián (1841-1847) que houve maior atenção ao oriente boliviano, com estímulo à colonização. Inclusive, quem conquistasse os índios “incivilizados", poderia se estabelecer em suas terras. No entanto, isso pouco adiantou para a efetiva colonização de lugares como o departamento de Santa Cruz. Somente na década de 1870, foi lançado um programa de colonização missional, como ponta de lança para a ocupação de terras nas "fronteiras internas" (JORDÁN, 2009, p. 35-48), sendo dada pouca atenção às fronteiras litigiosas nas terras baixas do leste, como a zona de fronteira com o Império do Brasil. Na verdade, o maior foco da Bolívia continuava sendo os países andinos, pois, na década de 1830, chegou a formar uma federação com o Peru, além de estar em conflito com o Chile desde então (KLEIN, 2010, p. 179-189). De toda forma, houve alguns estímulos para que particulares, notadamente utilizando mão de obra de grupos indígenas locais, procurassem se fixar no oriente boliviano, como veremos mais adiante.

O Império do Brasil, por sua vez, utilizou-se de aldeamentos como maneira de "ganhar" ou "assegurar" território, inclusive na zona de fronteira. Na segunda metade do século XIX, os grupos indígenas passaram a ter determinado papel nas formulações do governo central, com aplicação nas províncias, tanto para a colonização de determinadas áreas fronteiriças, como para serem "guardiões da fronteira", termo utilizado por Maldi (1997, p. 207), em relação ao período colonial, significando que determinados grupos indígenas deveriam assumir funções militares de defesa e ataque, em acordos com ibéricos ou mamelucos. Tal situação - a colonização de áreas "vazias" e a maior intenção de uso militar dos grupos indígenas - pode ser depreendida do fato de que, até 1845, não existia, em geral, nenhuma diretriz específica da Corte para os que fossem considerados índios (CUNHA, 1992), mesmo com a suspensão da "guerra justa" em 1831. Cabia às variadas regiões, estabelecerem suas ações relacionadas aos povos indígenas. Isso não significava que, desde a "extinção e abolição" dos Diretórios, em

Revista Eletrônica da ANPHLAC, ISSN 1679-1061, n.15, p. 5-36, jul./dez. 2013. http://revista.anphlac.org.br/ 
1798, fosse produzido um "vácuo" legislativo em relação a esses grupos, mas, sim, que as localidades aplicaram políticas próprias, sendo que as reformas de 1834 consolidaram as atuações descentralizadas e diversificadas referentes aos indígenas e suas terras (SAMPAIO, 2009).

A partir de 1845, foi elaborada e difundida uma política pelo governo central de "missões", cuja intenção era incentivar e regulamentar os aldeamentos e a catequese dos indígenas, sendo um de seus objetivos a assimilação dos aldeados que antes estariam "errantes". Com clara inspiração nos diretórios do século XVIII, haveria um diretorgeral na província e em cada aldeamento outro diretor, que podia ser clérigo ou leigo. Esperava-se que, reunindo os índios nesses aldeamentos, com o tempo passariam a ser "civilizados", pois supostamente aprenderiam ofícios, frequentariam escolas e, assim, adquiririam comportamentos sociais considerados adequados. No limite, o aldeamento não precisaria mais existir, transformando o lugar em um povoado ou vila de pessoas "civilizadas". No entanto, à medida que fossem sedentarizados em um lugar específico, suas amplas terras passariam para colonos diversos ou para o Estado (CUNHA, 1992, p. 133-139).

Almeida (2012, p. 159) nos mostra que eram extremamente diversificadas as maneiras como os povos indígenas respondiam aos apelos de aldeamento, sendo bem mais complexas do que a simples relação dominador/dominado. Tal como vimos no período colonial, a possibilidade de um novo aldeamento lograr êxito, no século XIX, dependeria do atrativo para os povos indígenas mudarem parte de sua maneira de viver. De toda forma, é importante notar que não deve ter sido à toa que promoveram aldeamentos em Mato Grosso, quando em toda província havia centenas de etnias, justamente entre os grupos ameríndios que habitavam a zona de fronteira ${ }^{9}$, logo nos limites ainda indefinidos do Império do Brasil com a Bolívia e o Paraguai.

$\mathrm{Na}$ Bolívia, por outro lado, somente houve um regulamento para as missões na década de 1870, como já foi destacado. No entanto, na década 1840, franciscanos já tinham apoio do governo para aldearem "índios bravios", inclusive na zona de fronteira (JORDÁN, 2009, p. 44). Também nas últimas décadas do século XIX, intensificaram-se as apropriações de terras indígenas no oriente boliviano, para criação de gado e

\footnotetext{
${ }^{9}$ Devo essa observação ao professor João Antônio Lucídio.

Revista Eletrônica da ANPHLAC, ISSN 1679-1061, n.15, p. 5-36, jul./dez. 2013. http://revista.anphlac.org.br/
} 
plantações, forçando muitos chiquitano a se mudarem para o Brasil (LEMA GARRET, 2009, p. 119).

De toda forma, podemos dizer que, na região fronteiriça, grupos indígenas também forneceram respostas variadas às tentativas de sedentarização e de transformação, no limite, em defensores e colonos da fronteira, o que, para os governos nacionais, poderia assegurar a posse de dada área, em um acordo internacional sobre limites, entre representantes dos Estados nacionais ${ }^{10}$. Dessa maneira, as respostas dos guaraio também não seguiram um padrão de relações, nem foram reduzidos da maneira como as autoridades governamentais pretendiam. Provavelmente, eram de origem guarani, habitavam regiões amazônicas, em áreas próximas ao rio Guaporé, transitando entre o que seria projetado ou imaginado como território da Bolívia e do Império do Brasil, ainda sem definirem limites institucionais. No final de 1852, um cidadão chamado Antônio Gomes da Silva estava encarregado de aldeá-los, a "50 léguas" da excapital, cidade de Mato Grosso, também conhecida por Vila Bela. Logo Gomes da Silva conseguiu que quatro casais, saídos do Pau-Cerne, do "lado boliviano", se mudassem para o "lado brasileiro", em uma área reservada para aldeamento. E afirmava confiante que outros 40 casais estariam dispostos a se mudar também. Somente não tinham ido ainda devido ao excesso de despesas necessárias para isso ${ }^{11}$. Ou seja, haveria que presenteá-los com instrumentos que aumentassem sua força produtiva, como machados e enxadas, pelo menos. Mas, nesse momento, as principais despesas estavam sendo com outros grupos indígenas já considerados aldeados no rio Paraguai.

O aldeamento dos guaraio passou a se chamar Santa Inês. Logo foram mais 14 casais e oito crianças, além dos que já estavam com o diretor da aldeia. Os que chegavam pediam de imediato o "batizado", conforme palavras dos dirigentes. Mas ainda restavam muitos, pois calculavam que em Pau-Cerne existiriam aproximadamente 1.240 guaraio $^{12}$. Pensavam que, com essa população, poderiam revitalizar a cidade de Mato Grosso, “onde tudo definha, e onde só a Mão de Deus pode fazer benefícios”,13,

\footnotetext{
${ }^{10}$ Sobre a necessidade de perceber, nas pesquisas, os índios não somente como grupos passivos, ou mesmo a dicotomia entre os que foram derrotados e os que resistiram frente às investidas dos "brancos", consultar Almeida (2008) e Boccara (2005b).

11 APMT. Diretoria Geral dos Índios (DGI). Henrique José Vieira para Augusto Leverger. 16 de dezembro de 1853. p. 26.

${ }^{12}$ Idem. p. 42.

${ }^{13}$ Idem.
}

Revista Eletrônica da ANPHLAC, ISSN 1679-1061, n.15, p. 5-36, jul./dez. 2013. http://revista.anphlac.org.br/ 
esperançava-se o diretor-geral dos índios. Certamente, uma das coisas que atraíam muitos povos era a possibilidade de utilizar produtos feitos de metais resistentes. Dessa maneira, eram encomendados, por exemplo, em 1855, 12 machados, 16 foices e 24 enxadas, "para serem distribuídos pelos índios guaraios", dizia o diretor-geral. Não sabemos se os índios se integraram à população da cidade de Mato Grosso. Mas o diretor da aldeia reclamava frequentemente da falta de recursos para continuar atraindo os índios da Bolívia para o Brasil. A redução também serviria para transformar índios em extrativistas da seringa, que começava a ser explorada. Porém, acabou desaparecendo tal aldeamento comandado por um diretor não índio (FONSECA, 1986, p. 157). De toda forma, pelo menos parte dos guaraio continuou vivendo nas matas do Guaporé, ocupando os dois lados pretendidos por bolivianos e brasileiros, sem serem seduzidos por nenhuma das novas nacionalidades, ao mesmo tempo, tendo que se deparar com os cabixi, grupo que também procurava dominar ou manter domínio de parte daquela região ${ }^{14}$.

Durante o império espanhol e depois, já no período republicano, García Jordán (2009) mostra que grupos guaraio já vinham sendo tenuemente aldeados. Era interesse da Coroa de Castela, desde o fim do século XVIII, procurar aldeá-los, mas não obteve grande sucesso, porque os guaraio se mostravam completamente refratários às formas de redução. Na década de 1820, quando alguns indígenas se sentiram ameaçados pela chegada de colonos brancos e mestiços nas terras baixas da antiga audiência de Charcas, eles mesmos fizeram uma petição às autoridades cruzenhas para serem aldeados, pois viam nisso uma possibilidade de manterem a segurança de parte do grupo. Os franciscanos teriam a incumbência de administrá-los. Alguns aldeamentos desapareceram, outros surgiram, mas houve alguns que puderam ser considerados “exitosos” pelos missionários, principalmente depois da década de 1880 (JORDÁN, 2009, p. 69-91).

No entanto, ao que tudo indica, esses aldeamentos não visavam à fronteira internacional da Bolívia, servindo, no máximo, para que os aldeados não fossem

\footnotetext{
${ }^{14}$ Esse grupo por vezes atacava, matando e saqueando arraiais perto de Vila Bela, o que fazia o governo enviar expedições para detê-los (APMT. D.G.I). Henrique José Vieira para Augusto Leverger. Cuiabá, 16 de dezembro de 1853). Por outro lado, em vez de procurar exterminá-los, as diretrizes para se tratar com os grupos indígenas tinham mudado. Assim, procuravam atrair, sem sucesso, esse grupo para o incipiente aldeamento dos guaraio (APMT. DGI). Henrique José Vieira para Antônio Gomes da Silva. Cuiabá, 5 de agosto de 1854).
}

Revista Eletrônica da ANPHLAC, ISSN 1679-1061, n.15, p. 5-36, jul./dez. 2013. http://revista.anphlac.org.br/ 
atraídos por representantes do Brasil, como vimos no caso dos propósitos da aldeia de Santa Inês, ao passo que, no Império, os novos aldeamentos em Mato Grosso foram estrategicamente localizados na zona fronteiriça.

Dois dos aldeamentos com maior população foram instalados na beira do rio Paraguai, no sul da província: o de Albuquerque, com predominância dos guaná, e o de Nossa Senhora do Bom Conselho, com predominância dos quiniquináo. Ambos reuniam várias etnias, inclusive alguns guaicuru, conhecidos por serem guerreiros indômitos $^{15}$. É interessante notar que, antes, a posse de cavalos e o seu comércio continuavam entre esses indígenas, que "vagueiam em ambas margens do Paraguai"16, ao passo que outros preferiram fazer parte das reduções. De toda forma, observa-se que as reduções não eram prisões. Muitos praticavam comércio ao longo dos rios. Outros povos se estabeleciam perto dessas reduções, sem necessariamente serem parte delas. As duas reduções mencionadas ficavam perto de fortes, podendo abastecer esses lugares com o que produziam. No entanto, quando explodiu a guerra contra o Paraguai, foram completamente destruídas. Não por acaso, formou-se um grupamento especial de índios guaicuru para guerrear contra as tropas guaranis, além de outros povos, como os terenas, que foram incorporados à Guarda Nacional. A participação no conflito contra o Paraguai não seria necessariamente uma adesão dessas etnias à "nação brasileira", mas talvez tenha ocorrido pelo costume de guerra, no caso do histórico de guaicuru contra os assucenhos e guaranis, ou como uma forma de retaliação à hostilidade recente dos paraguaios no território em que viviam. Assim, se os grupos indígenas na fronteira participavam da política internacional desses países platinos em formação, mais uma vez demonstravam que tinham atitudes próprias durante a formação dos Estados nacionais, mesmo na condição de aldeados ${ }^{17}$.

Um outro grupo indígena que habitava desde as regiões de fronteira com a Bolívia até perto de Goiás e São Paulo eram os genericamente chamados de bororo. Eram classificados em três subgrupos: os "da campanha", os "cabaçal" e os "coroado". Se poderiam ser considerados índios "mansos" na época da colônia, por se aliarem aos

\footnotetext{
${ }^{15}$ APMT. DGI. Henrique José Vieira para Augusto Leverger. Cuiabá, 16 de dezembro de 1853.

${ }^{16}$ APMT. Diretoria Geral dos Índios [documento sem data, danificado, início da documentação do Diretório, em 1848].

${ }^{17}$ Sobre a participação desses grupos na guerra do Paraguai e consequências nos territórios indígenas, ver Oliveira e Pereira (2007).
}

Revista Eletrônica da ANPHLAC, ISSN 1679-1061, n.15, p. 5-36, jul./dez. 2013. http://revista.anphlac.org.br/ 
portugueses na guerra contra os caiapó (MANO, 2010, p. 332), no período imperial, o último subgrupo seria representado como o maior terror que poderia existir. Na tentativa de abertura de uma estrada ligando Cuiabá a São Paulo, com a consequente colonização de áreas em que os bororo viviam, esses indígenas reagiram fortemente, estabelecendo um conflito extremamente sangrento por aproximadamente 50 anos, até que foram, nos dizeres da época, "pacificados" e aldeados. Podemos levar em conta a proposta de Evangelista (2011, p. 41-48), de que a aceitação de participar de um aldeamento, mudando parte de seu modo de vida, seria compensada por outro benefício. No caso, a proposta de "pacificação" e a consequente participação de aldeamentos poderiam ter sido, naquele momento, vantajosas, haja vista o tempo e o desgaste do conflito. Seja como for, outros subgrupos de bororo, antes da metade do século XIX, já tinham sido aldeados por fazendeiros da região de Vila Maria (Cáceres), ou seja, na área de fronteira.

Tudo indica, contudo, que os bororo possuíam ainda grupos que viviam na região fronteiriça sem ser reduzidos, como vários outros índios. Normalmente considerados índios do Brasil (GRASSO, 1985, p. 438), eles também eram temidos pelos chiquitano, na Bolívia. Por vezes, entravam nas vilas ou roças chiquitanas, para levar o que pudessem e matar a quem a eles se opusessem. Dessa maneira, um habitante essencial para a política de fronteira, Sebastián Ramos, chefe da colônia de San Matías, orgulhava-se de ter sido ele o pacificador dos bororo, que, segundo ele, tinham praticado tantos roubos e assassinatos, mas agora se prestavam a auxiliar em diversos serviços públicos. Ramos dizia poder contar praticamente apenas com os bororo para que sua colônia ficasse tranquila, pois era um lugar para onde se enviavam condenados pela justiça boliviana. Para ele, o melhor serviço que esses indígenas faziam era capturar fugitivos da colônia. De toda forma, quando estabeleceu relações com eles, fez notar que quase todos falavam e respondiam em espanhol e em português, o que mostra como esses grupos tinham diversas formas de contato com os chamados "civilizados".

Em um livro sobre a história de San Matías, sem fazer referência a documentos, Peinado Cuéllar e Rivero Yavarí (2007, p. 30) argumentam que a cidade foi formada por imigrantes descendentes de europeus e por pessoas vindas principalmente das exmissões da Chiquitanía, mas os índios "Bororó no incurrieron en casi nada en la historia del pueblo, en su formación, en su organización, crescimento demográfico etc.”. Revista Eletrônica da ANPHLAC, ISSN 1679-1061, n.15, p. 5-36, jul./dez. 2013. http://revista.anphlac.org.br/ 
Viraram trabalhadores em uma fazenda e seus descendentes moravam em uma pequena comunidade chamada San Joaquin. Ou seja, para os autores, os bororo eram um grupo impermeável e monolítico, praticamente desconsiderando as possibilidades de miscigenação e transformação. Era como se fossem contagiosos, haja vista o horror que os moradores dessa parte da fronteira tinham de brasileiros, não somente devido ao constante temor de que as autoridades do Brasil reconsiderassem outra a posição de seus limites, mas também devido às pessoas que assaltavam esse lugar, conhecidos por "los fumacianos" (CUÉLLAR; YAVARÍ, 2007, p. 98), pois viviam em uma área chamada "Fumaça", que acabaram dando nome a um lugar, na zona fronteiriça, de "Bandidos da Fumaça".

Certamente, mesmo com as tentativas de colonização, aldeamentos, concessão de terrenos, muito da região de fronteira era desconhecida ou insatisfatoriamente conhecida, assim como parte de sua população. Depois do tratado de 1867, que causou tantas controvérsias, foi realizada uma expedição para colocar os marcos nos principais pontos que delimitariam a fronteira, separando, enfim, essa região em duas jurisdições, pelo menos nominalmente. O comandante da expedição era um militar, Severiano da Fonseca, que havia estudado a região antes da viagem, inclusive as línguas indígenas. $\mathrm{O}$ interesse era tanto topográfico, como relacionado aos povos silvícolas do lugar. A descrição que foi feita sobre a jornada, que durou de 1875 a 1878, mostra não somente o desconhecimento prévio de partes geográficas da zona fronteiriça por parte dos "civilizados" - com mapas bastante inexatos ou obscuros, considerando-se o que a cartografia do século XIX requeria -, mas também quão intrigante foi ele ter se deparado com um povo do qual nunca se havia tido notícia. Seus integrantes tinham tido contato havia pouco, cerca de quatro anos, com uma pequena guarnição militar. Severiano da Fonseca observou que eles falavam uma língua diferente das usadas geralmente no vale do Guaporé, "entremeando vocábulos portugueses e espanhóis" (FONSECA, 1988, p.190). Mas achava que parecia com o "dialeto galibi", que era praticado na região entre as Guianas e o Brasil. Também tinha elementos do tupi e caraíba, ou seja, percebia-se, pelas classificações linguísticas, que era muito misturada. Eles não sabiam dizer "a sua procedência ou origem", o que poderia ajudar na tarefa de classificação, trabalho geralmente empregado pelos colonizadores, mais ainda de governantes ou autoridades de fronteira. De seu contato com alguns deles, conseguiu

Revista Eletrônica da ANPHLAC, ISSN 1679-1061, n.15, p. 5-36, jul./dez. 2013. http://revista.anphlac.org.br/ 
entender que haviam vivido no Baures, onde de fato existira missão, e depois se dispersaram por várias regiões. Fonseca, intrigado com esses índios, colheu a seguinte informação de um canoeiro que já estava se acostumando a tratar com eles: tinham sido levados pelos espanhóis, cujo principal tinha o nome de Ignácio, que escolhera para mulher uma das ameríndias. De toda forma, entre esses índios havia alguns "verdadeiramente brancos, de cabelos avermelhados ou castanhos" (FONSECA, 1988, p. 191). A pessoa mais respeitada era uma índia branca, de olhos azuis. Era tratada por "senhora" por todos da tribo, único nome dado a ela. Esse grupo tinha sido encontrado havia poucos anos, e passaram a chamá-lo de palmela, devido ao lugar. Existiam uns 400 indivíduos, registrou o expedicionário (FONSECA, 1986, p. 190-206).

Quando a expedição partiu, tinha sido embarcado no bote um pequeno índio palmela. Em dado momento, já tendo percorrido certa distância rio abaixo, chegaram ao forte Príncipe. O canoeiro principal, dono da embarcação, que podemos chamar de "ribeirinho", saiu com o menino para o povoado de São Joaquim, para encontrar algumas pessoas, e voltou sem o palmela. Era ainda o tráfico de escravos índios que permanecia nesses lugares, lamentava-se Severiano da Fonseca (1986, p. 235), seguindo seus pesares de acordo com o pensamento da monarquia após 1845. Depois, a expedição percorreu "enormes ermos", sem encontrar ninguém por muitos quilômetros, com seu barco cujos remadores eram "índios bolivianos", todos recrutados anteriormente, juntos, em um mesmo lugar, sendo um caiobá, outro baures e outros itomana, que, por algum dinheiro, se dispuseram a percorrer grandes distâncias. O militar notou em sua pesquisa linguística que a fala deles continha palavras características de regiões desde o alto Amazonas até o quéchua andino, passando pelo guarani, além de espanhol. Ou seja, a diversidade linguístico-cultural na zona de fronteira era enorme, como também era grande a extensão de lugares efetivamente não conhecidos e não dominados pelos "brancos" no século XIX, assim como as distâncias entre eles.

\section{A criação da fronteira linear - argumentos, posições e o primeiro acordo}

$\mathrm{Se}$ as autoridades governamentais, com seus desejos de classificação e conhecimento dos diversos povos e da geografia física demonstravam, ainda na segunda metade do século XIX, considerável desconhecimento, havia outras partes que os

Revista Eletrônica da ANPHLAC, ISSN 1679-1061, n.15, p. 5-36, jul./dez. 2013. http://revista.anphlac.org.br/ 
governantes locais não somente conheciam, mas sabiam de sua importância estratégica. Mais do que esse conhecimento, eles procuravam a melhor maneira de representá-las em seus discursos para tratar com o país vizinho.

Era necessário estabelecer as fronteiras como decorrência da formação dos novos países, como já aludimos anteriormente. Assim, tanto a Bolívia como o Império do Brasil mandaram representantes para o país vizinho, com a finalidade de ao menos iniciarem as bases dos diálogos para a futura demarcação. Em uma dessas idas e vindas, o representante brasileiro, Duarte da Ponte Ribeiro, que mais tarde viria a ser um dos principais diplomatas e conselheiros do Império, escrevia que "em consequência deste Tratado [o de 1777] que se tem feito de grande importância", o que prontamente o presidente da província de Mato Grosso retrucou, argumentando que considerá-lo poderia causar problemas. O presidente era Pimenta Bueno, o futuro marquês de São Vicente e titular de mais de um ministério, inclusive das Relações Exteriores. Ele fazia notar que se fosse considerado tal tratado, partes como "os edifícios de Casalvasco e outros pontos importantes que hoje existem" poderiam ser fortemente questionadas ${ }^{18}$. Esses lugares tinham sido construídos na década de 1780, ou seja, depois do tratado, ocupando parte a oeste do Guaporé, o que seria do "lado espanhol".

Assim, a estratégia do Império brasileiro passou a ser desqualificar o antigo tratado colonial. Enquanto os representantes da Bolívia insistiam que tal acordo era o melhor para fundamentar a delimitação entre os países, os brasileiros passaram a fazer a representação de que tinha acontecido uma guerra entre Espanha e Portugal em 1801, o que suspendia todos os tratados anteriores. Depois disso, não houve novo acordo durante o período colonial. Os representantes do Império também passaram a argumentar que o Tratado Preliminar de Santo Ildefonso era, como o próprio nome indicava, somente preliminar, não tendo sido nunca ratificado pelas partes. De fato, os demarcadores nunca concluíram seu trabalho de delimitação. Essa região estava longe de ser a mais importante dos impérios ibéricos, notadamente do espanhol, a ponto de envidarem grandes esforços para traçar uma linha divisória ainda no tempo das soberanias sobre reinados. Buarque de Holanda (1986, p. 120) lembra que, para a Espanha, nos momentos em que estabelecia acordos com Portugal, no século XVIII,

\footnotetext{
${ }^{18}$ APMT - Registro de Correspondência com outras Províncias e a Bolívia. Pimenta Bueno para Duarte da Ponte Ribeiro, Encarregado dos Negócios do Brasil em Chuquisaca. Cuiabá, 5 de maio de 1837.

Revista Eletrônica da ANPHLAC, ISSN 1679-1061, n.15, p. 5-36, jul./dez. 2013. http://revista.anphlac.org.br/
} 
lugares como as ilhas Molucas, na Indonésia, eram muito mais importantes e promissores do que as terras de pântanos e florestas no centro da América do Sul. Mesmo quando encontraram ouro em Mato Grosso, essas regiões continuaram escassamente povoadas. Por isso, podemos dizer que a ideia de "gênio" português, que foi tão propagada, não teria como contrapartida uma suposta "ingenuidade espanhola". Para os espanhóis, não existia nesses lugares - com forte presença de indígenas, difíceis de conquistar - nada que superasse as possibilidades já alcançadas das minas andinas ou do México.

De toda forma, quando surgiram os Estados nacionais na América, não havia um direito internacional que pudesse arbitrar as questões territoriais. Evocava-se frequentemente um fluido e plástico "Direito das Gentes" ou "Naturais". Segundo Chiaramonte (2010, p. 53 e ss.), os pensadores desse direito, que podiam ser desde suíços a hispânicos, foram muito citados como parâmetro nas guerras de independência. Ele asseguraria o direito dos súditos de se rebelarem contra o soberano em caso de mau governo. Teria base medieval e foi reciclado quando pretendiam separar-se da metrópole. Depois, foi usado entre países com interpretações diferentes. Para os brasileiros, em relação ao vizinho boliviano, ele era evocado para articular o direito de propriedade, no caso, dos escravos que fugiam para a Bolívia. Assim, requisitavam a entrega dos cativos fugitivos com base no "Direito das Gentes"19. As autoridades bolivianas, por sua vez, utilizavam o mesmo direito para não entregar os que tinham fugido, pois feriria o princípio de liberdade garantido nesse direito. $\mathrm{O}$ mesmo ocorria em relação às possessões concedidas em áreas litigiosas. Recorriam a esses princípios, não solidamente estabelecidos e universalmente codificados, para que não ocupassem ou saíssem de determinado lugar. É interessante notar que, nas correspondências entre as províncias, não citavam nenhum autor, somente que existia esse direito, baseado em "costume". Era um direito que concorria paralelamente com o direito positivo das constituições, que passaram a ser marca distintiva desses novos países que surgiam.

Assim, desde a primeira Constituição boliviana, a escravidão era proibida, e todo aquele que entrasse em solo boliviano seria considerado livre. E dessa maneira, a Bolívia se apresentava como avessa ao cativo e à extradição de negros fugidos nas

\footnotetext{
${ }^{19}$ APMT. RCPB. Manoel Alves Ribeiro para Governador e Chefe da Província de Chiquitos. Cuiabá, 2 de setembro de 1843.
}

Revista Eletrônica da ANPHLAC, ISSN 1679-1061, n.15, p. 5-36, jul./dez. 2013. http://revista.anphlac.org.br/ 
relações com o Brasil, conforme documentos do Itamarati (CALDEIRA, 2009). No entanto, nas práticas de fronteira, isso não acontecia de fato. Fazia parte das pautas iniciais do governo brasileiro a devolução de escravos. Se oficialmente era negada a "restituição", contraditoriamente, os representantes do Brasil na fronteira recorriam ao tratado de 1777, para que os escravos fossem devolvidos. E de fato foram, não devido a nenhum tratado, mas a recompensas pagas na fronteira aos que entregassem os cativos. Chegou-se mesmo a formar expedição, sem nenhuma contestação do governo de Santa Cruz, para entrar no território boliviano e "resgatar" os escravos negros ${ }^{20}$.

Ainda podemos acrescentar que a escravidão negra persistia na Bolívia, na segunda metade do século XIX, mesmo longe de ser a forma de trabalho predominante. Secreto (2011), baseada em bibliografia sobre o tema, nota que, nas legislações da Bolívia, o país não se tornaria "solo livre" da escravidão nas primeiras constituições e legislações, mas somente na Carta Magna de 1851. No entanto, em 19 de setembro de 1853, o prefeito de Santa Cruz mandava uma circular para outras autoridades do departamento, para que soubessem do "zelo", "patriotismo" e "filantropia" do cidadão Juan de Soría, por ter emprestado seu cativo negro Antonio Ribas, para trabalhar na obra da Santa Catedral até sua conclusão ${ }^{21}$.

De toda forma, a devolução de escravos acabou saindo da pauta de negociações com a Bolívia. Quando o tratado foi assinado em 1867, não havia mais espaço no ocidente para requerer a "propriedade" de volta, principalmente por meio diplomático. No próprio Brasil, já era apontado que, mais cedo ou mais tarde, a escravidão iria acabar. Era questão de tempo. Se na década de 1830 muitos proprietários chegaram a pensar em levantar fundos para fazer frente à Inglaterra, em um possível conflito para a defesa do tráfico, depois de 1850, com a lei Euzébio de Queiroz, essa instituição condenada por toda parte demonstrava seu crepúsculo (PARRON, 2011).

Talvez, a recusa oficial da Bolívia em devolver escravos se devesse não somente à maneira como o novo país fundado por revolucionários libertadores queria se apresentar ao mundo, mas também para ter algum trunfo nas negociações de limites com o Brasil. Tal trunfo acabou perdendo a validade. E o interesse das autoridades

\footnotetext{
${ }^{20}$ APMT. RCPB. José Antônio Pimenta Bueno para Duarte da Ponte Ribeiro, Encarregado dos Negócios do Brasil em Chuquisaca. Cuiabá, 11 de maio de 1838.

${ }^{21}$ Museo de História y Archivo Histórico de Santa Cruz. (MHAHSC). Prefectura del Departamento de Santa Cruz, 19 de setembro de 1853. Código 1/32-20, legajo 67, fondo prefectural.
}

Revista Eletrônica da ANPHLAC, ISSN 1679-1061, n.15, p. 5-36, jul./dez. 2013. http://revista.anphlac.org.br/ 
bolivianas era ter acesso ao Atlântico, mesmo com sua sociedade mais voltada para os Andes e o Pacífico.

Os governantes do Brasil, por sua vez, sabiam que dirigentes da Bolívia procuravam colonizar partes não muito conhecidas por eles, com a esperança de que achassem uma ligação para o rio Paraguai e daí para o mar. Dessa maneira, a publicação do jornal boliviano Semanário anunciava a concessão de terreno a Manoel Luiz Oliden, em uma área do departamento de Santa Cruz de la Sierra. Poderia contar com a ajuda dos índios chiquitano, e esperava-se que não só conseguiria prosperar com as riquezas da terra, como também construir um porto em um dos rios da região que fosse desaguar no Paraguai ${ }^{22}$. Mas não conseguiu achar rio nenhum que pudesse fazer essa ligação. Uma de suas tentativas foi enviar seu filho, para que, navegando no rio Paraguai, encontrasse uma vertente que desse na província de Oliden (o lugar ocupado pelo concessionário passou a ser chamado assim). Porém, o governo brasileiro impediu tal travessia, não deixando que passasse por Vila Maria. Perto desse lugar, tinha se estabelecido Sebastião Ramos, ex-governador de Chiquitos, que já havia mudado seu rancho de lugar devido às pressões do governo de Mato Grosso. Ainda iria se retirar do novo lugar, Tremedal, para depois mudar-se para San Matías, após vários apelos do governo brasileiro ao governo de Santa $\mathrm{Cruz}^{23}$, procurando afastá-lo dos rios Paraguai e Jauru.

Outro que tentou se estabelecer na região fronteiriça, com esperanças de ligar Santa Cruz ao rio Paraguai, foi o alemão chamado de Maurício Bach. Pretendia ocupar áreas consideradas desabitadas ou mesmo desconhecidas. Utilizou mão de obra indígena e, por um momento, dedicou-se à produção de cacau e algodão, entre outros. Mas perdeu tudo em um incêndio (RADDING, 2005, p. 352). Ele também atuava como funcionário da província de Chiquitos. Em 1845, dirigiu-se a Cuiabá pela estrada da antiga capital, Vila Bela. Dizia que iria para o Rio de Janeiro fazer negócios e, então, pretendia passar pela área perto de Vila Maria, atravessando a área das Salinas. Mas foi impedido pelas autoridades e obrigado a retornar por Vila Bela até a Bolívia. Era

\footnotetext{
${ }^{22}$ Archivo y Biblioteca Nacional de Bolivia (ABNB). El Semanario, n. 5, 17 de novembro de 1832.

${ }^{23}$ Entre outros, ver APMT. RCPB. José da Silva Guimarães para João da Costa Rego Monteiro, Encarregado de Negócios do Brasil. Cuiabá, 15 de julho de 1843.
}

Revista Eletrônica da ANPHLAC, ISSN 1679-1061, n.15, p. 5-36, jul./dez. 2013. http://revista.anphlac.org.br/ 
acusado de espião pelo governo brasileiro. Bach discordava disso e pediu ao governo imperial indenização pelos danos causados ${ }^{24}$.

$\mathrm{Na}$ verdade, essa área, conhecida como "Salinas do Jauru", passou a ser alvo do governo provincial, com destacamento militar, por ter um marco perto do rio Jauru, que deságua no rio Paraguai. O significado simbólico desse lugar remetia à ideia de que houve uma demarcação decorrente do tratado de 1777, e o rio representaria a borda do território boliviano. Aconteceu que o governo de Mato Grosso conseguiu controlar essa área, retirando a possibilidade de acesso ao rio Paraguai pela Bolívia. Para um boliviano chegar a Cuiabá, não poderia passar por Vila Maria, caminho antigo e conhecido desde a época das missões jesuíticas, mas, sim, teria que entrar pela cidade de Mato Grosso (Vila Bela) e obrigatoriamente mostrar passaporte ${ }^{25}$. Ao mesmo tempo, autoridades provinciais procuravam assegurar que a navegação pelo rio Jauru, que poderia ter sido a fronteira entre a Espanha e Portugal pelo tratado colonial mais citado da época, o de 1777, ficasse sob navegação exclusiva de embarcações brasileiras.

Estava claro que, enquanto não existisse tratado, o Brasil tinha vantagem em tomar a ofensiva territorial, ao mesmo tempo em que procurava deter pessoas que, em nome do governo boliviano, tentavam não só se instalar, mas também passar e conhecer a zona fronteiriça, enquanto a Bolívia, por seu turno, podia refugiar escravos, além de abrigar fugitivos da justiça brasileira, como já foi referido. Assim, as autoridades bolivianas demonstravam que também conseguiam estabelecer certo controle na zona fronteiriça, como tinha sido o caso do bando armado, fugido de Vila Bela.

Quando se deu o tratado de Ayacucho, em 1867, ficou estipulado que nem o Império, nem a Bolívia dariam asilo a pessoas consideradas criminosas em seus respectivos países. Se antes a navegação pela bacia amazônica não era franqueada, passou a ser de livre trânsito, de acordo com o novo acordo assinado no tempo caloroso da guerra contra o Paraguai.

É importante notar que a navegação pelos principais rios platinos foi um dos principais fatores para a eclosão do conflito. Como mostra Doratioto (2003), a região do Prata vivia de maneira conturbada, desde o período colonial, e não menos nas décadas

${ }^{24}$ ABNB, Caja 8, Saturnino Sousa Oliveira para M.R.E. de Bolívia. Rio de Janeiro, 29 de outubro de 1847.

${ }^{25}$ APMT. RCPB. Pimenta Bueno para Governador da Província de Chiquitos, Marcelino de la Peña. Cuiabá, 8 de julho de 1837. p. 56-57.

Revista Eletrônica da ANPHLAC, ISSN 1679-1061, n.15, p. 5-36, jul./dez. 2013. http://revista.anphlac.org.br/ 
seguintes às independências. Em resumo, havia mudanças constantes de direcionamentos entre a "livre-navegação" e o protecionismo na região platina, tendo como fatores de acentuação do clima belicoso as intervenções de Buenos Aires e do Império do Brasil em Montevideo. Ao mesmo tempo, o Paraguai se solidificava como país soberano frente às pretensões portenhas, mas sem saída marítima garantida. Regiões como Corrientes, que veio depois a ser incorporada definitivamente à Argentina, flertava com a possibilidade de apoiar o Paraguai em um possível confronto, que pudesse ajudá-lo a ter acesso ao Atlântico. Por outro lado, mesmo tendo sido acordado entre o Brasil e o país guarani a "livre navegação", em 1856, pelo rio que cortava o Paraguai (o que, de fato, não acontecia como previsto, devido a uma série de embargos), o problema da linha fronteiriça entre ambos persistia, assim como o trânsito nos rios platinos. Para os brasileiros, entre outros fatores, significaria ter melhor acesso à província de Mato Grosso, cuja viagem encurtaria em meses e aumentaria em volume. Os dois países viam que, em determinado momento, deveriam demarcar o limite territorial. Os paraguaios insistiam para que fosse no rio chamado de Branco. Não muito distante dali, o Império não abria mão para que fosse rio Apa. Ao que tudo indica, quando Lópes resolveu ocupar a parte sul de Mato Grosso, e antes, quando prendeu um presidente de província que iria para Cuiabá, em um vapor, no final de 1864, o governante pensava poder contar com dissenções do Uruguai e com o apoio das regiões de Corrientes e Entre Rios. Mas os possíveis aliados acabaram recuando quando o conflito estourou. Com a criação da Tríplice Aliança, em 1865, segundo Isekson (2009), o destino do Paraguai estaria selado. Ou seja, ao contrário de a guerra ter sido provocada pelos interesses britânicos na região, Doratioto mostra que foram as tensões e interesses que existiam nessa mesma região que fizeram iniciar a "tempestade no Prata" (DORATIOTO, 2003, 23-106).

Assim, foi durante a maior guerra da América do Sul, que o Império assinou o primeiro tratado com a Bolívia, temeroso de que os dirigentes bolivianos apoiassem o país guarani (DORATIOTO, 2002, 263-264). Com o tratado de 1867, do que dependesse do Império, a navegação para o sul, pela bacia platina, seria franca para as embarcações bolivianas ou de interesse desse país. Em relação ao que seria o tratado de Santo Ildefonso para o tratado de Ayacucho, foi calculada uma perda territorial de aproximadamente 400 mil quilômetros quadrados. Assim, quando se deu o acordo, logo

Revista Eletrônica da ANPHLAC, ISSN 1679-1061, n.15, p. 5-36, jul./dez. 2013. http://revista.anphlac.org.br/ 
em seguida, senhores proprietários, comerciantes e demais pessoas de Santa Cruz de la Sierra protestaram veementemente contra o que foi estipulado pelo tratado diplomático (PEÑA et al., 2011, p. 68-69).

Um dos argumentos para esse tratado era o uti possidetis. O problema era que havia grandes áreas que não eram ocupadas, nem eram efetivamente conhecidas pelas autoridades, como foi expressa pela viagem de Severiano da Fonseca, do mesmo modo como ocorria na Bolívia (PEÑA et al., 2011, p. 47). Não havia posse útil para ter uti possidetis. Mesmo áreas como as Salinas, à direita do rio Paraguai, foram ocupadas por representantes de Estado, num momento em que a região fronteiriça estava em litígio e indefinida. Desse modo, é extremamente simples o argumento de que o Império defendia o uti possidetis, enquanto a Bolívia lutava pelo tratado de 1777, pois as coisas se davam de maneira diferente: esse último acordo colonial, do XVIII, poderia servir de proposição, dependendo das circunstâncias, como no caso da fuga de escravos.

Muitos que habitavam a zona de fronteira provavelmente não deixaram de viver como viviam, ou de projetar seu futuro, independentemente do tratado de 1867. As principais energias das autoridades bolivianas estavam voltadas para os Andes e o Pacífico. Poucos anos depois do tratado, que poderia ter facilitado o acesso ao Atlântico, a Bolívia perdeu sua província litorânea (1883), em uma guerra na qual era aliada do Peru, contra o Chile. O país passaria a depender mais ainda das relações externas para poder ter fluxos internacionais. Mesmo assim, seu foco de ações demoraria a se voltar ao seu oriente, possuidor de uma grande zona fronteiriça com o Brasil, sujeita ainda a muitos ajustes pelos Estados nacionais, mas vivida por uma grande variedade de grupos com estratégias diversas, mudadas com o tempo ${ }^{26}$.

\section{Considerações finais}

Como uma das características dos novos Estados nacionais era o estabelecimento de linhas de fronteira, a região por onde esse traço imaginado passaria apresentava características que seus centros políticos não poderiam deixar de considerar, nem Chuquisaca, nem o Rio de Janeiro. Eram os senhores donos de escravos, em Mato Grosso, que reclamavam seus cativos fugidos para o país vizinho,

\footnotetext{
${ }^{26}$ Ver, por exemplo, Silva (2008), sobre problemas recentes de identificação étnica e de nacionalidade, na fronteira do Brasil com a Bolívia.
}

Revista Eletrônica da ANPHLAC, ISSN 1679-1061, n.15, p. 5-36, jul./dez. 2013. http://revista.anphlac.org.br/ 
supostamente com "solo livre". Tinha sido para o novo país ao lado - que continuou com a tradição monárquica - que o governador realista de Chiquitos recorrera para fugir dos independentistas, mas que depois se tornou republicano convicto. Era averiguando a melhor condição para migrar ou permanecer, que grupos indígenas avaliavam seus destinos nas terras instáveis. Tratar da região de fronteira como um lugar que fornece respostas e perguntas certamente não significa que estaria desconectada das partes centrais de seus países. No entanto, ao ser destacado um lugar ao qual pretendiam confluir, não somente instituições nacionais e seus representantes, mas também pessoas que não se imaginavam nessas novas "comunidades nacionais" ligadas às formas de Estado, é possível ver como a região de fronteira é um lugar propício para reformulações e hibridações. Assim, existiam e atuaram na fronteira desde grupos que, por vezes, usufruíam de benefícios momentâneos de um aldeamento, para depois seguirem outros rumos, como os chamados de guaraio, no Guaporé; ou de outra maneira, parte dos bororo, que tiveram destino diferente em San Matías, ao não serem reduzidos, como foram em Mato Grosso, depois de intensa luta; ou os palmela, que causavam estranheza, assumindo forma de comunidade e identificação até então desconhecida; além de outros que deveriam existir e estar se reformulando.

Se os espaços por vezes poderiam ser considerados "vazios", mal puderam ser preenchidos com os aldeamentos, fundações de vilas e colonizações de algumas terras, da maneira que dirigentes do século XIX desejavam. Extensões vastas e escassamente conhecidas pelas autoridades nacionais não os impediam de recorrer à magia dos mapas, para traçar o que não tinha sido efetivamente tangido e de que, mesmo assim, tomavam posse juridicamente, mas que, na verdade, era um lugar vivido por uma grande variedade de pessoas, que brigavam, se dispersavam e mesmo se misturavam, sem se pensar como nacionais dos novos países: "bolivianos" e "brasileiros". Seria muito difícil imaginar o canoeiro e o pequeno palmela, referidos por Fonseca na década de 1870, identificando-se com esses atributos; o ribeirinho, dono do bote, muito provavelmente não se identificaria; o garoto palmela, traficado no vale guaporeano, a probabilidade negativa seria maior ainda, para não dizer nula.

\section{Referências Bibliográficas}

Revista Eletrônica da ANPHLAC, ISSN 1679-1061, n.15, p. 5-36, jul./dez. 2013. http://revista.anphlac.org.br/ 
ALMEIDA, Maria Regina Celestino de. Índios e mestiços no Rio de Janeiro: significados plurais e cambiantes (séculos XVIII-XIX). In: Memória Americana, n. 16, p. 19-40, 2008.

. Os índios na história do Brasil. Rio de Janeiro: FGV, 2010.

Populações indígenas e Estados nacionais latino-americanos: novas abordagens historiográficas. In: AZEVEDO, Cecília; RAMINELLI, Ronald (Org.). História das Américas: novas perspectivas. Rio de Janeiro: FGV, 2011, p.105-133.

História e Antropologia. In: CARDOSO, Ciro Flamarion; VAINFAS, Ronaldo. Novos domínios da história. Rio de Janeiro: Elsevier/Campus, 2012, p.151-168.

ANDERSON, Benedict. Nação e consciência nacional. [Imagined Communities]. São Paulo: Ática, 1989.

BAUD, Michael. Ideologías de raza y nación en América Latina, siglos XIX y XX. In: MARTINS, Estevão de Rezende (Dir.); BRIGNOLI, Héctor Pérez. (Coord.). Teoría y metodología en la Historia de América Latina. Paris: Unesco/Trotta, 2006, p. 175- 194.

BASTOS, Uacury Ribeiro de Assis. Expansão territorial do Brasil colônia no vale do Paraguai (1767-1801). São Paulo: FFLCH/ USP, 1979.

BOCCARA, Guillaume. Génesis y estructura de los complejos fronterizos euroindígenas. Repensando los márgenes americanos a partir (y más allá) de la Obra de Nathan Wachtel. In: Memoria Americana, n. 13, p. 21-52, 2005 a.

Mundos nuevos en las fronteras del Nuevo Mundo. In. Nuevo

Mundo Mundos Nuevos [On-line], Debates, posto on-line no dia 8 fev. 2005b. Disponível em: <http://nuevomundo.revues.org/426>. Acesso em: 25/04/2013.

BORGES, Carolina da Silva. Nas margens da história. Meio ambiente e ruralidade em comunidades "ribeirinhas" no Pantanal Norte - 1870-1930. Cuiabá: EDUFMT/Carlini \& Caniato, 2010.

CALDEIRA, Newman di Carlo. À procura da liberdade. Fugas internacionais de escravos negros na fronteira oeste do Império do Brasil (1822-1867). In. Nuevo Mundo Mundos Nuevos. Maio de 2009. Disponível em: $<$ http://nuevomundo.revues.org/56190>. Acesso em: 20/09/2013.

CALÓGERAS, J. Pandiá. A política exterior do Império. Brasília: Senado Federal, 1998. Edição fac-similar.

CARVALHO, Francismar Alex Lopes de. Cruzando fronteiras e negociando lealdades: índios missioneiros entre os domínios ibéricos de Mojos, Chiquitos e Mato Grosso (c. 1767-1800). In: Nuevo Mundo Mundos Nuevos [En línea], p. 1-26, 2012. Disponível em: 〈http://nuevomundo.revues.org/62485>. Acesso em: 23/04/2013.

CERVO, Amado L.; BUENO, Clodoaldo. História da política exterior do Brasil. Brasília: UnB/IBRI, 2011.

CHIARAMONTE, José Carlos. Fundamentos intelectuales y políticos de las independencias: notas para una nueva historia intelectual de Iberoamérica. Buenos Aires: Teseo, 2010.

Revista Eletrônica da ANPHLAC, ISSN 1679-1061, n.15, p. 5-36, jul./dez. 2013. http://revista.anphlac.org.br/ 
COSTA, José Eduardo Fernandes Moreira da. A formação do território chiquitano. In: SILVA, Joana Fernandes (Org.). Estudos sobre os chiquitanos no Brasil e na Bolívia. Goiânia: UCG, 2008. p. 167-219.

CUÉLLAR, René Peinado; YAVARÍ, Willy Freddy Rivero. San Matías, la esperanza de la libertad. Santa Cruz de la Sierra: Fundación Nova/Gráfica Sirena, 2007.

CUNHA, Manuela Carneiro da. Política indigenista no século XIX. In.

História dos índios no Brasil. São Paulo: Companhia das Letras, 1992. p. 133-154.

DORATIOTO, Francisco. Maldita guerra: nova história da Guerra do Paraguai. São Paulo: Companhia das Letras, 2003.

FERREIRA, Andrey Cordeiro. Conquista colonial, resistência indígena e formação do Estado-Nacional: os índios guaicuru e guana no Mato Grosso dos séculos XVIII-XIX. In: Revista de Antropologia, v.52, n.1, p. 97-133, 2009.

FONSECA, João Severiano da. Viagem ao redor do Brasil [1875-1878] [Tipografia de Pinheiro \& C., 1881]. Rio de Janeiro: Biblioteca do Exército Editora, 1986. Vol. 1 e 2.

FOUCHER, Michel. L'invention des frontières. Paris: F.E.D.N., 1986. Obsessão por fronteiras. São Paulo: Radical Livros, 2009.

GARCIA, Elisa Frühauf. As diversas formas de ser índios: políticas indígenas e políticas indigenista nos extremo sul da América portuguesa. Niterói, 2007. Tese (Doutorado em História) - Programa de Pós-Graduação da Universidade Federal Fluminense. Niterói, 2007.

GARRET, Ana María Lema. El sentido del silencio - La mano de obra chiquitana en el Oriente boliviano a principios del siglo XX. Santa Cruz de la Sierra: UPIEB/ El País, 2009. Colección Ciencias Sociales.

GRASSO, Dick E. Ibarra. Pueblos indígenas de Bolivia. La Paz: Libreria Editorial G.U.M., 1985.

GUERRA, François-Xavier. Modernidad e independencias. Madrid: Encuentro, 2009.

HOLANDA, Sérgio Buarque de. O extremo oeste. São Paulo: Brasiliense, 1986.

ISECKSON, Vitor. A Guerra do Paraguai. In: GRINBERG, Keila; SALLES, Ricardo. O Brasil imperial. Rio de Janeiro: Civilização Brasileira, 2009. Vol. II. (1831-1870). p. 385-425.

JANCSÓ, István; PIMENTA, João Paulo. Peças de um mosaico (apontamentos para o estudo da emergência da identidade nacional brasileira). In: MOTA, Carlos Guilherme (Org.). Viagem incompleta. A experiência brasileira - 1500-2000. São Paulo: Senac, 2000. p. 127-175.

JORDÁN, Pilar García. Cruz y arado, fusiles y discursos: la construcción de los Orientes en el Perú y Bolivia 1820-1940. Lima: IFEA/IEP, 2001.

. Unas fotografías para dar a conocer al mundo la civilización de la república guaraya. Madrid: CSIC, 2009.

KLEIN, Herbert S. O fim da sociedade colonial e a criação de uma nação independente (séculos XVIII e XIX). In: PAMPLONA, Marco A.; MÄDER, Maria Elisa (Org.).

Revista Eletrônica da ANPHLAC, ISSN 1679-1061, n.15, p. 5-36, jul./dez. 2013. http://revista.anphlac.org.br/ 
Revoluções de independências e nacionalismos nas Américas: Peru e Bolívia. Rio de Janeiro: Paz e Terra, 2010. p. 129-191.

KOK, Glória. Fronteiras índias nos "dezertos, ainda indecizos, pella linha imaginária". Século XVIII. Nuevo Mundo Mundos Nuevos [En línea], p. 1-12, 2011. Disponível em: <http://nuevomundo.revues.org/62012>. Acesso em: 02/03/2013.

LEVERGER, Augusto. Relatório de Presidente de Província. Cuiabá: Tipographia Provincial, 1863.

MALDI, Denise. De confederados a bárbaros: a representação da territorialidade e da fronteira indígenas nos séculos XVIII e XIX. In: Revista de Antropologia, São Paulo, v.40, n.2, p. 183-221, 1997.

MANO, Marcel. Metáforas históricas e realidades etnográficas. A construção de uma história do contato kayapó no Triângulo Mineiro. In: Cadernos de Pesquisa do CDHIS, Uberlândia, v.23, n.2, jul./dez. 2010.

MELlO, Arnaldo Vieira de. Bolívar, o Brasil e os nossos vizinhos do Prata - da questão de Chiquitos à Guerra da Cisplatina. Rio de Janeiro: Editora Escopo, 1963.

MOREIRA, Vânia Maria Louzada. De índio a guarda nacional: cidadania e direitos indígenas no Império (Vila de Itaguaí, 1822-1836). In: Topoi, v.11, n.21, p. 127-142, jul.-dez. 2010.

OLIVEIRA, J. Eremites de; PEREIRA, L. M. "Duas no pé e uma na bunda": da participação terena na guerra entre o Paraguai e a Tríplice Aliança à luta pela ampliação de limites da terra indígena buriti. In: Revista Eletrônica História em Reflexão, Dourados, v. 1, n. 2, p. 1-20, jul./dez. 2007.

PAMPLONA, Marco A.; DOYLE, Don H (Org.). Nação e nacionalismo no novo mundo: a formação de Estados-nação no século XIX. Rio de Janeiro/São Paulo: Record, 2009.

PARRON, Tamis. A política da escravidão no Império do Brasil - 1826-1865. Rio de Janeiro: Civilização Brasileira, 2011.

PEÑA, Paula Hasbún et al. La permanente construcción de lo cruceño: un estudio sobre la identidad de Santa Cruz de la Sierra. Santa Cruz: Universidad Autónoma Gabriel René Moreno, 2011.

QUIJADA, Mónica. El paradigma de la homogeneidad. In:

BERANAND, Carmen; SHNEIDER, Arnd. Homogeneidad y Nación - Con un studio de caso: Argentina siglos XIX y XX. Madrid: Consejo Superior de Investigaciones Científicas, 2000. p. 15-55.

RADDING, Cynthia. Paisajes de poder e identidad. Fronteras imperiales en el desierto de Sonora y bosques de la Amazonía. Sucre: FCBCB - Archivo y Biblioteca Nacionales de Bolivia, 2005.

RECIO, José María García. Análisis de una sociedad de frontera. Santa Cruz de la Sierra en los siglos XVI y XVII. Sevilla: Gráficas del Sur/Diputación Provincial de Sevilla/Archivo Histórico Nacional de Bolivia, 1988.

Revista Eletrônica da ANPHLAC, ISSN 1679-1061, n.15, p. 5-36, jul./dez. 2013. http://revista.anphlac.org.br/ 
ROCA, José Luis. Ni con Lima ni con Buenos Aires: la formación de un Estado nacional en Charcas. La Paz: IFEA/ Plural editores, 2007.

SAMPAIO, Patrícia Melo. Política indigenista no Brasil Imperial. In: GRINBERG, Keila; SALLES, Ricardo. O Brasil imperial. Rio de Janeiro: Civilização Brasileira, 2009. Vol. I. (1808-1831). p.175-206.

SANTOS, Luís Cláudio Villafañe Gomes. O Império e as repúblicas do pacífico. As relações do Brasil com Chile, Bolívia, Peru, Equador e Colômbia (1822-1889). Curitiba: UFPR, 2002.

SANZ, Jorge Alejandro Ovando. La invasión Brasileña a Bolivia en 1825. La Paz: Libreria Editorial "Juventud", 1986.

SECKINGER, Ron L. La cuestión de chiquitos: una breve crisis en las relaciones boliviano-brasileñas. In: Revista de la Universidad Gabriel René Moreno, n.39-40, p. 7$31,1985$.

SECRETO, María Verónica. Soltando-se das mãos: liberdades dos escravos na América Espanhola. In: AZEVEDO, Cecília; RAMINELLI, Ronald. História das Américas novas perspectivas. Rio de Janeiro: Ed. FGV; EdUFF, 2011. p.135-159

SILVA, Joana Fernandes. Identidades e conflitos na fronteira: poderes locais e os Chiquitanos. In: Memoria Americana, v. 16, n. 2, p.119-148, 2008.

VANGELISTA, Chiara. Los indios como recurso económico. El caso de Mato Grosso (Brasil), siglos XIX-XX. In: JORDÁN, Pilar García (Ed.). El Estado en América Latina. Recursos e imaginarios, siglos XIX-XXI. Barcelona: Publicacions i Edicions de la Universitat de Barcelona; TEIAA, 2011. p. 41-58.

VOLPATO, Luiza. A conquista da terra no universo da pobreza: formação da fronteira oeste do Brasil - 1719-1819. São Paulo: Hucitec, 1987.

Revista Eletrônica da ANPHLAC, ISSN 1679-1061, n.15, p. 5-36, jul./dez. 2013. http://revista.anphlac.org.br/ 